\title{
THE EFFECTIVENESS OF LAVENDER AROMATHERAPY IN REDUCING THE LEVEL OF DYSMENORRHEA IN ADOLESCENT GIRLS
}

\author{
Rahayu Savitri ${ }^{1}$, Ovi Hardyanti ${ }^{1}$ \\ ${ }^{1}$ STIKes Budi Luhur Cimahi \\ Corresponding email: $\underline{\text { rahayu_savitri@yahoo.co.id }}$
}

\begin{abstract}
Dysmenorrhoea is pain during menstruation accompanied by cramps in the lower abdomen that spreads to the back and thighs, the pain usually occurs on the first or second day of menstruation and reaches its peak in the first 24 hours. Lavender Aromatherapy is one of the nonpharmacological therapies to decrease the intensity of dysmenorrhea. The purpose of this research was to determine the effectiveness of lavender aromatherapy in reducing dysmenorrhea in adolescent girls. This research is a quantitative study using a pre-experimental method with One Group Pretest Posttest approach. The purposive sampling technique used in this study, the sample was 34 respondents. Data collection tools used a pain measurement scale and the observation sheet. The data were analyzed using the dependent T-Test with $\alpha$ $=0.05$. The results of this research obtained the dysmenorrhea scale before aromatherapy was moderate pain $(76.5 \%)$ after aroma-therapy reduced become mild pain $(55.9 \%)$. The T-test found p-value $0.000<\alpha$ (0.05). There is an influence of aromatherapy in reducing in the teenagers (girls) Conclusion: There is the influence of aromatherapy in reducing pain scale in the teenagers (girls). Young women can lavender aromatherapy as alternative non-pharmacological therapies to solve dysmenorrhea and advice have active roles in managing their dysmenorrhea.
\end{abstract}

Keywords: Effectiveness, dysmenorrhea, lavender aromatherapy, teenage girls.

\section{INTRODUCTION}

Adolescence is a period of transition that characterized by changes in physical, emotional and psychic developments. Adolescence, between the ages of 10-19 years is a period of maturation of human reproductive organs and often called puberty (Rohan \& Siyoto, 2013). Puberty is characterized by rapid body growth, changes in Genetalia function, and the presence of the menarche (first menstruation). Menstruation is regular bleeding as a sign that the gynecologist has functioned (Kusmiran, 2014). The menstrual process takes place regularly every month on every normal woman starting about 14 days after ovulation (Sukarni \& Rev, 2013).

Dysmenorrhoea is pain during menstruation usually occurs on the first or second day and reaches its peak in the first 24 hours. Dysmenorrhea has an impact on school-age adolescents, including they leave their school program routine for several hours or several days. The sense of insecurity experienced by a young woman if not resolved immediately will be the mental and physical function of the young woman so that it is very important to do actions or therapies that can reduce the pain when Menstrual (dysmenorrhea). There are two types of Dysmenorrhea, the primary and secondary dysmenorrhea. The primary dysmenorrhea is a menstrual pain often encountered by teenagers (girls) without the underlying cause. Secondary dysmenorrhea is a menstrual pain caused by gynecology disorders or other diseases (Sukarni and Revelation 2013).

The prevalence of dysmenorrhea incidence is still high, the world's dysmenorrhea incidence rate reaches 90\% (Holder, 2014). According to the World Health Organization (WHO, 2012) data, 
the incidence of 1,769,425 inhabitants (90\%) Women who experience dysmenorrhea with 10$15 \%$ experiencing severe levels. An estimated $50 \%$ of all women in the world suffer from dysmenorrhea in a menstrual cycle (Calis, 2011). A dysmenorrhea incidence rate in Indonesia amounted to 107,673 people $(64.25 \%)$, consisting of 59,671 people $(54.89 \%)$ Primary Dysmenorrhea (Kallo, 2012). As the number of dysmenorrhea events in West Java is still high, $54.9 \%$ of women suffer from dysmenorrhea, consisting of $24.5 \%$ mild, $21.28 \%$ moderate, and 9.36\% severe level (Arnis, 2012).

Dysmenorrhea can be treated in two ways, pharmacological and non-pharmacological therapy (Kumalasari \& Andyantoro, 2012). One of these nonpharmacological therapies is aromatherapy, which aims to reduce the level of pain. The Aromatherapy was lavender aromatherapy, where the essential oil is inhalation, the pen kits receptor cells are stimulated and impulses are transmitted to the emotional center of the brain, or the limbic system (Marzouk et al, 2013).

Aromatherapy can reduce the level of pain in dysmenorrhea, this is because aromatherapy can provide a stimulating effect, giving a soothing sensation, a soothing sensation of the brain, a balance, a soothing sensation Stress, relaxation to the mind and physique of the body. So this effect would reduce the level of pain of dysmenorrhea in someone and when the mind is calm and relaxed it will create a comfortable atmosphere, and decreased menstrual pain (NAJMI, 2011).

The Aromatherapy Lavender (Lavandula angustifolia) gives the effect in reducing the intensity of pain in menstruation (Yuliana, et al (2016). It is because of the main ingredient in lavender (Lavandula angustifolia) is linalyl acetate and Linalool (C10H180). Linalool is the main active ingredient that contributes to the effect of relaxation on lavender that has a soothing psychological efficacy. In addition, essential oils of lavender (Lavandula angustifolia) can reduce the level of anxiety, and can improve one's mood (goddess, 2013). The purpose of this research was to determine the effectiveness of lavender aromatherapy in reducing dysmenorrhea in adolescent girls

\section{METHODS}

The research was a quantitative study using pre-experimentation approach (Pre-experimental designs) with one group Pretest-Posttest, there were two times measurements for the same respondents. The times of measurement include before and after the administration of Aromatherapy. The treatment of lavender aromatherapy was 20 minutes, after the treatment, the next action was measuring the level of pain.

The population in this research was student year X and XI students, it was 369 students. The samples were chosen using non-probability sampling techniques. The samples were teenagers (girls) as many as 34 students (respondents) with the provisions of inclusion and exclusion that had been established by the researcher.

Data collection used tools including observations using the scale checklist sheet 10-point pain with Word description, Standard operational procedure (SOP) Aromatherapy Lavender, lavender aromatherapy essential as well as the form to be provided with the recording of respondent data. The observation sheet uses an intensity scale of 10-point pain and performs 
inhaler aromatherapy lavender using lavender aromatherapy 3 drops by mixing with $20 \mathrm{ml}$ of water.

\section{RESULTS}

The results of the research presented in 4 different tables

Table 1. The scale of menstrual pain (dysmenorrhea) before aromatherapy.

\begin{tabular}{lll}
\hline \multirow{2}{*}{ Pain Levels } & \multicolumn{2}{c}{ Result } \\
\cline { 2 - 3 } & Frequency & Presentage \\
\hline Moderate Pain & 26 & $76,5 \%$ \\
Severe Pain & 8 & $23,5 \%$ \\
\hline Total & 34 & $100,0 \%$ \\
\hline
\end{tabular}

Table 1 presents that 26 girls $(76.5 \%)$ had dysmenorrhea with moderate level and 8 of them (23.5\%) with severe level.

Table 2. The scale of menstrual pain) after aromatherapy

\begin{tabular}{lll}
\hline \multirow{2}{*}{ Pain levels } & \multicolumn{2}{c}{ Result } \\
\cline { 2 - 3 } & Frequency & Percentage \\
\hline No Pain & 15 & $44,1 \%$ \\
Mild Pain & 19 & $55,9 \%$ \\
\hline Total & 34 & $100,0 \%$ \\
\hline
\end{tabular}

Table 2, shows that aromatherapy has been given to 15 people (44.1\%) The dysmenorrhea are on a painless scale, and most of the 19 people (55.9\%) The dysmenorrhea are at the scale of mild pain.).

Table 3. Test results of normality variable level of menstrual pain (dysmenorrhoea) in teenagers(girls) classes X and XI before and after the given of lavender aromatherapy

\begin{tabular}{llll}
\hline \multirow{2}{*}{ Pain Scale } & \multicolumn{3}{c}{ Result } \\
\cline { 2 - 4 } & Skweness & Standar Error & Distribusi Data \\
\hline $\begin{array}{l}\text { Pain Scale } \\
\text { Before }\end{array}$ & $-0,417$ & 0,403 & $-1,03$ ( Normal) \\
\hline $\begin{array}{l}\text { Pain Scale } \\
\text { After }\end{array}$ & 0,218 & 0,403 & 0,54 (Normal) \\
\hline
\end{tabular}

Based on the analysis, the study $n$ table 3 test the normality of obtained data that the pain scale variables prior to the Aromatherapy Lavender obtained a value of 1.03 and a variable pain scale after administered lavender aromatherapy Obtained a value of 0.54 , then all data is declared as a normal distribution because the value of skewness/SE is between values-2 to 2 . Therefore, the test used is using a parametric statistical test (for Sample T-Test). 
Table 4. Test result dependent parametric statistical Sample T-Test on the scale of menstrual pain (dysmenorrhea) before and after the given of lavender in the teenagers (girls) class $\mathrm{X}$ and XI

\begin{tabular}{lllllll}
\hline & \multicolumn{6}{c}{ Result } \\
\cline { 2 - 7 } Pain Scale & \multicolumn{2}{c}{ Variable Value } & \multicolumn{3}{c}{ Composite Value } \\
\cline { 2 - 7 } & $\mathbf{N}$ & Std. D & $\begin{array}{l}\text { Std. } \\
\text { Error }\end{array}$ & Mean & t & P \\
& 34 & 0,904 & 0,155 & 5,82 & 39,754 & 0,000 \\
\hline Before & 34 & 1,043 & 0,179 & 1,06 & & \\
After & 34 & & & & &
\end{tabular}

Based on the results of the analysis of parametric statistical trials of the Sample T-Test in table 4 above, the data obtained that the average period of menstrual pain (dysmenorrhoea) before given the value of aromatherapy lavender mean (5.82) with standard deviation (0.904) and standard error (0.155). Meanwhile, the average menstrual pain level (dysmenorrhoea) after aromatherapy lavender mean value (1.06) with standard deviation (1.043) and standard error (0.179). From the results of parametric statistical test, Sample T-Test obtained p-value 0.000. Because P-value of $<\alpha(0.05)$ then $\mathrm{Ha}$ is accepted and $\mathrm{H} 0$ is rejected. It is thus concluded that "there is a significant effect between the scale of menstrual pain (dysmenorrhoea) before and after the given of lavender in teenagers (girls) of class X and XI".

\section{DISCUSSION}

Dysmenorrhea is a pain that is felt during menstruation accompanied by cramps in the lower abdomen that would spread to the back and thighs, usually occurs on the first and second days of menstruation. Pain is a subjective and personal feeling.

Dysmenorrhea is caused by the changes in the hormone levels that are excessive in the body, as a result, is a contraction in the muscles of the uterus so that the uterine muscles to strain. This might because of the increase of Prostaglandin levels in the body.

The Given of lavender aromatherapy affects the reduction in the scale of menstrual pain (dysmenorrhoea), It is in line with the concept of Najmi (2011), said that aromatherapy can reduce the pain level in a person who has undergone dysmenorrhoea because aromatherapy can provide a stimulating effect, giving a soothing sensation of self, The sensation of soothing the brain, the balance, the soothing sensations of stress, relaxation to the mind and physique of the body. If the mind feels calm and relaxed it will create a comfortable atmosphere so that the painful menstruation is reduced. In addition, this supported results from several research journals concluded that the essential oil of lavender (Lavandula angustifolia) can provide relaxation benefits (carminative), sedative, reduced levels of anxiety, and being able to improve the mood of a person (goddess, 2013

Based on the explanation of result, it is proven that all respondents experienced a significant pain change after the given of lavender aromatherapy. This research is following the theory of Marzouk et al, (2013) says that some of the alternative therapies that can be done by nurses for the treatment of Dysmenrhoea are by using aromatherapy. Aromatherapy is used as a complementary therapy in nursing practice by using essential oils from fragrances plants to alleviate health problems and to improve one's life in general. Aromatherapy can be used as an alternative to reduce levels of dysmenorrhoea pain. When the essential oil is inhalation, the pen 
kits receptor cells are stimulated and impulses are transmitted to the emotional center of the brain, or the limbic system. Aromatherapy can provide relaxing, and calming effects, in addition to improving blood circulation. Aromatherapy is cheap and safe therapy for DYSMENRHOEA.

\section{CONCLUSION}

Dysmenorrhoea experienced by the teenagers (girls) of class X and XI before being given lavender aromatherapy, it almost entirely within a moderate pain range. The majority of participants in the moderate pain level. It also can be said that in this research there is a significant difference between (DYSMENORRHOEA) before and after the given of lavender in the teenagers (girls) class X and XI and in this study there are differences Significant between the menstrual pain Scale (dysmenorrhoea) before and after the given of lavender aromatherapy in the teenagers (girls) X grade and XI. It is evidenced by the value $\mathrm{P}=0.000<\alpha$ value $=0.05$.

\section{REFERENCES}

Dahlan. (2016). Besar Sampel Dalam Penelitian Kedokteran Dan Kesehatan. Edisi 4. Jakarta : Epidemiologi Indonesia.

Dasinah. (2017). Pengaruh Aromaterapi Relaksasi Lavender Terhadap Penurunan Tekanan Darah Pada Pasien Penderita Hipertensi. Skripsi. STIKes Budi Luhur Cimahi.

Dewi. (2013). Aromaterapi Lavender Sebagai Media Relaksai. Bagian Farmasi Fakultas Kedokteran Universitas Udayana. Bali. Diakses Pada Tanggal 15 Januari 2018.

Indriyani, Diyan. (2013). Keperawatan Maternitas Pada Area Perawatan Antenatal. Yogyakarta : Graha Ilmu.

Jaelani (2009). Aromaterapi. Jakarta : Yayasan Pustaka Obor Indonesia.

Kartika Retnowati. (2015). Efektifitas Implementasi Kompres Hangat Terhadap Perubahan Skala NyeriHaid (Dismenorea) Pada Siswi Kelas XI di Madrasah Aliyah Negeri (MAN) Cimahi. Skripsi. STIKes Budi Luhur Cimahi.

Kusmiran, Eny. (2014). Kesehatan Reproduksi Remaja dan Wanita. Jakarta : Salemba Medika.

Maharani, Yulianan Vivian, dkk. (2016). Pengaruh Aromaterapi Lavender (Lavandula Angustifolia) Terhadap Intensitas Nyeri Haid (Dismenorea) Pada Mahasiswa STIKes Madani Yogyakarta. Jurnal Kesehatan Madani Medika, Volume 7, Nomor 1, hal 43-49. Diunduh 15 Januari 2018.

Marmi. (2015). Kesehatan Reproduksi. Yogyakarta : Pustaka Pelajar.

Marzouk. T, A.M.R El-Nemer, and H.N Baraka. (2013). The Effect Of Aromatherapy Abdominal Massage On Alleviating Menstrual Pain In Nursing Students: A Prospective 
Rahayu Savitri : The Effectiveness of Lavender Aromatherapy in Reducing

Randomized Cross-over Study. Evidence-Based Complementary and Alternative Medicine Volume 2013. Diakses pada Tanggal 17 January 2018.

Najmi, L, N. (2011). Buku Pintar Menstruasi. Yogyakarta : Wardi.

Ningsih, R. (2011). Efektifitas Paket Pereda Terhadap Nyeri pada Remaja Dengan Dismenorea di SMAN Kecamatan Curup. Tesis. Universitas Indonesia. Diakses pada tanggal 15 januari 2018.

Notoadmodjo. (2012). Metodologi Penelitian Kesehatan. Jakarta : Rineka Cipta.

Nursalam. (2016). Metodologi Penelitian Ilmu Keperawatan. Edisi 4. Jakarta: Salemba Medika.

Prasetyo \& Nian. (2010). Konsep dan Proses Keperawatan Nyeri. Yogyakarta: Graha Ilmu.

Purwanto, Budhi. (2013). Herbal dan Keperawatan Komplementer. Yogyakarta: Nuha Medika.

Riyanto, Agus. (2011). Pengolahan dan Analisis Data Kesehatan. Yogyakarta: Nuha Medika.

Rohan \& Siyoto. (2013). Buku Ajar Kesehatan Reproduksi. Yogyakarta: Nuha Medika.

Savitri, Rahayu. (2015). Gambaran Skala Nyeri Haid Pada Usia Remaja. Jurnal Keperawatan Aisyiyiah Volume 2. No. 2. Desember 2015. Diunduh Pada Tanggal 18 Januari 2018.

Sugiyono. (2017). Metode Penelitian Kuantitatif Kualitatif dan $R \& D$. Bandung: Alfabeta.

Sukarni \& Wahyu. (2013). Buku Ajar Keperawatan Maternitas. Yogyakarta: Nuha Medika.

Wahyuningsih. (2014). Efektifitas Aromaterapi Lavender (Lavandula Angustifolia) dan Massage Effleurage Terhadap Tingkat Nyeri Persalinan Kala I Fase Aktif Pada Primigravida di Bps Utami dan Ruang Ponek RSUD Karanganyar. Skripsi. Diunduh Pada Tanggal 15 Januari 2018. 